IJLRES - International Journal on Language, Research and Education Studies

ISSN: 2580-6777 (p); 2580-6785 (e)

DOI: 10.30575/2017/IJLRES-2018010403

Vol. 2, No. 1, 2018

Page: $34-43$

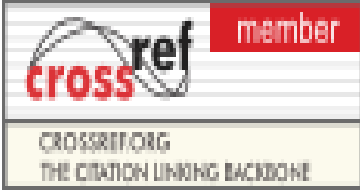

\title{
UNDERSTANDING ANALYSIS AND TEACHER PREPARATION IMPLEMENT CURRICULUM 2013
}

\author{
Siti Halimah \\ State Islamic University of North Sumatra Medan, Indonesia \\ sitihalimah@uinsu.ac.id
}

\begin{abstract}
This research aims to describe: understanding, approval, readiness, and preparation of teachers implementing curriculum 2013; inhibiting factors and support implementing curriculum 2013. The type of research used in this research is a survey with its informants are PAI (Islamic Religious Education) teachers who are assigned to various schools and madrasahs who are attending Starta-2 education at UIN-SU Postgraduate. Data collection tools used in this research are tests, questionnaires, and interviews. Research findings: (1) understanding of good category PAI teachers; (2) The teacher approval to implement curriculum 2013 of 18 people (95\%) answered agree and as many as 3 people (5\%) answered less; (3) teacher readiness in implementing curriculum 2013 as many as 19 people (97\%) ready to implement and as many as 2 people $(3 \%)$ not ready; (4) preparatory steps of the teacher: (a) learn the essence of curriculum 2013, design Lesson Plan (RPP), media $\mathcal{E}$ assessment techniques, read the rules, engage in the KKG; (5) inhibiting and supporting factors implementing curriculum 2013: (a) lack of facilities $\mathcal{E}$ infrastructure, (b) lack of teachers' books and students' books, (c) lack of teacher knowledge (d) time limitations. Driving factors: (a) there are teachers' books and students' books, (b) there is support from the manager, (c) there is provision (c) having adequate awareness, and adequate skills.
\end{abstract}

Keywords: Analysis, understanding, readiness of teachers, implementing curriculum 2013

\section{INTRODUCTION}

Islamic education is an integral part of national education. It is contained in Law No. 20 of 2003 on National Education System article 37 paragraph 1, which stated that the curriculum of elementary and secondary education must include religious education. In the explanation section stated that the religious education intended to form learners into a human being who believes and piety to The One Almighty God and have a noble character. The intended purpose can be realized well if the curriculum concept and the implementation of the curriculum are held simultaneously and in tandem. This 
is important because the implementation of a curriculum has an impact on what should be done in an educational process.

Until now there are still many schools that implement the Education Unit Level Curriculum (KTSP). Although the results of KTSP evaluation are considered to have the following weaknesses: (1) over-emphasize the cognitive aspect, (2) too many subjects (causing the burden and suffering of elementary students, (3) too broad and the deepness of the content or material, (4) as well as the lack of effort to inculcate a positive attitude, and the character of the nation's generation.

Various things above have impacted on the curriculum results that have not succeeded in educating the character of the young generation of Indonesia, which is indicated from every day we are treated to news about the treatment of violence, crime, infidelity, corruption. In addition, the youth, students and student university who are expected to be the backbone of the nation have involved with drugs, pornographic VCDs, and gambling. All of these examples are challenges for education to immediately make changes by doing curriculum rearrangement.

Other issues that arise in relation to the concepts and implementation as well as the results of the curriculum of Islamic Religious Education (PAI), including:

- The concept of the PAI's lesson curriculum is critically overcrowded in mission rather than the number of functions and objectives that students expect after learning Islamic Religious Education (PAI).

- Too solid material with seven main elements of faith, worship, qur'an, moral, muamalah, syari'ah and tarikh taught separately to cause the material too while the allocation of teaching time is limited,

- Submission of the material is too shallow and strongly oriented to the delivery of cognitive domains mainly in terms of the purpose of subject matter and the evaluation tools used,

- The implementation of PAI learning is more verbalistic. The learning approach tends to be normative without accompanied by illustrations of socio-cultural context so that students are less able to appreciate the values of religion as the value of life in their daily life.

On the basis of various phenomena above, designed of curriculum and learning needs to be done soon. But in the midst of the urge to immediately implement curriculum 2013 as a refinement of the previous curriculum, another issue that arises is 
the unpreparedness of teachers implementing or implementing curriculum and assessment according to the demands of curriculum 2013. The learning process in K-13 requires implementation by using scientific approach cannot be implemented entirely by teachers including teachers of Islamic religious education. In addition, the assessment of authentic assessment based learning is very burdensome and less applicable in implementing curriculum 2013.

The empirical facts above, encourage authors to do a critical study of the understanding and readiness of PAI teachers to implement curriculum 2013, addressing the following key issues:

1. What is the understanding, approval and readiness and preparatory steps of teachers to implement curriculum 2013 ?

2. What factors are the obstacles and supporters of PAI teachers implementing curriculum 2013 ?

\section{LITERATUR REVIEW}

\section{Concept of Curriculum 2013}

Basic policy of Curriculum 2013 with reference to the Regulation of the Minister of Education and Culture of RI:

- Number 20 of 2016 about Standard of Competence of Primary and Secondary Education Graduates

- Number 21 of 2016 about Basic and Secondary Education Content Standards

- Number 22 of 2016 about Standard Process of Primary and Secondary Education

- Number 23 of 2016 about Standards Assessment

- Number 24 of 2016 about Core Competencies and Basic Competencies of Curriculum Lesson 2013 about Basic Education and Secondary Education

Curriculum 2013 is designed with the aim of preparing the people of Indonesia who have the ability to live as individuals and citizens who are faithful, productive, creative, innovative and affective and able to contribute to the life of society, nation, state and civilization world. ${ }^{1}$ The learning process of Curriculum 2013 by applying the principles of learning as follows:

1. From the learners are told to the participants to find out

\footnotetext{
${ }^{1}$ Arrange Team of Regulation of Ministry of Education and Culture, 2014, p. 10
} 
2. From the teacher as the only source of learning to be learning based on various sources of learning

3. From textual approach to process as strengthening the use of scientific approach

4. From content-based explanations to competency-based learning

5. From partial learning to integrated learning

6. From learning that emphasizes single answers to learning with multidimensional truth answers

7. From learning verbalism to applicative skills

8. Improvement and balance between physical skills (hards skill)

9. Learning that prioritizes the culture and empowerment of learners as lifelong learners

10. Learning that implements values by giving exemplars (ing ngarso sung tulodo), building willingness (ing madyamangunkarso), and developing the creativity of learners in the learning process (tut wuri handayani)

11. Learning that takes place at home, at school, and in the community

12. Learning that implements the principle that anyone is a teacher, anyone is a student, and everywhere is a class

13. Utilization of information and communicative technology to improve the efficiency and effectiveness of learning

14. Recognition and individual differences and cultural background of learners

The learning process of curriculum 2013 is a process of interaction between learners with educators and learning resources that exist in the learning environment with reference to the syllabus that has been developed by the government. The learning process is done based on activity and activity of student learning by using scientific approach (scientific). ${ }^{2}$ Curriculum 2013 learning strategy aims to improve the quality of education of the nation's children in reasoning, understanding, implementation, so that they are able to train the formation of character education and able to develop the qualities of educators in shaping spiritual, social, knowledge and skill attitudes.

\section{METHODOLOGY}

${ }^{2}$ Regulation of Ministry of Education and Culture Republic of Indonesia Number 22, Year 2016 about Process Standard in Elementary and Secondary Level. 


\section{Siti Halimah}

In accordance with the focus of the problems raised, the qualitative research method with survey approach. The research data information was obtained from PAI teachers who served in various schools and madrasah who were studying Starta-2 at UIN-SU Postgraduate. The data collection tools used in this research are: test, questionnaire, and interview.

\section{FINDINGS AND DISCUSSION}

In accordance with the focus of the problem, the findings of this study inform:

The level of understanding of teachers from the test results obtained an average value of 76.50 (good category). Professional educators (teachers) are not only required to perform their duties professionally, but also must have the knowledge and professional skills.

According to Nana Syaodih Sukmadinata there are three general dimensions of ability that must be possessed by teachers, namely: (a) mastery of the subject matter, including the mastery of the material to be taught and the basic knowledge of the material; (b) the mastery of the foundations and insights of education and teacher training; (c) mastery of the process of education, teacher training and student learning. ${ }^{3}$ Various abilities that must be owned by teachers have a close relationship with the mastery of teachers and or teacher science about the curriculum 2013 as one of the dimensions of fulfillment of professional skills of professional teachers must master the foundation and insights of education and teacher, and mastery of the process of education, teacher and student learning in accordance with the curriculum demands imposed.

Teacher approval implementing Curriculum 2013, based on the results of the questionnaire to inform: as many as 95\% (18 people) agree to implement, and as many as 5\% (3 people) disagree. The statement agreed to implement the 2013 curriculum for the following reasons:

- Curriculum 2013 contains a moral message that matches the breath and goals of the PAI

\footnotetext{
${ }^{3}$ Nana Syaodih Sukmadinata, (2011), Pengembangan Kurikulum: Teori dan Praktek, Bandung: Remaja Rosdakarya, hal. 191
} 
- Curriculum 2013 simplifies teacher work because it has prepared teacher books and student books and syllabus

- Curriculum 2013 equally contains aspects of knowledge, skills with attitude mendahukan

- Agreed to implement curriculum 2013 because the learning process is carried out satisfactorily by using a scientific approach that activates the process of thinking scientific students

- Agree to implement curriculum 2013 because it has become the demands of the times While the statement does not agree and less agree with the reasons as follows:

- Teachers do not understand to do it

- Socialization of the implementation of the curriculum is still less widespread

- Difficult in completion of administration

The teacher approval statement provides a positive reason for curriculum 2013. This indicates that the curriculum 2013 of the result of teacher analysis has a strong reason to be implemented immediately to improve the quality and quality of learning and curriculum outcomes. The enactment of curriculum 2013 replaces the previous curriculum on the grounds that the formulation of the Graduate Competency Standards in the Curriculum 2013 draws direction and / or objectives that can manifest a fullfledged human being. That is, conceptually curriculum 2013 has advantages, among others: (a) using a natural approach (contextual); (b) based on character and competence, so that mastery of science can be applied by students in daily life. Thus the teacher's approval of the implementation of curriculum 2013 is based on strong assumptions and reasons.

While the disagreements of teachers implement curriculum 2013, due to their inability to implement it in accordance with the demands of curriculum and policies imposed due to the lack of knowledge and skills of teachers to implement the curriculum 2013. Recognized that an innovation of course has a variety of barriers such as is associated with the perpetrator (agent) innovation itself is the teacher as the executor of the curriculum. Although it is understood that curriculum implementation is a challenge in improving the condition of education in Indonesia. Teachers need to realize that they are the key to the success of the education process at school / madrasah. Therefore, the 


\section{Siti Halimah}

fundamental and important thing faced by teachers is the mental readiness to change the curriculum.

Readiness of teachers to implement the curriculum 2013 as many as nineteen (19) people and not ready for two (2) people with the following reasons:

- Teachers are ready to implement curriculum 2013 by preparing RPP and teaching media

- Teachers are ready to implement curriculum 2013 by utilizing learning tools that have been prepared by the government

- Teachers are ready to implement curriculum 2013 by preparing mentally and accepting changes

- Teachers are ready to implement curriculum 2013 with the provision of knowledge and skilled workshop results and training that has been implemented

While teachers who are not ready to implement curriculum 2013 for various reasons as follows:

- Not ready as it still needs more reinforcement of Curriculum 2013

- Not ready for training and training on implementation of Curriculum 2013

- Not too ready because not have enough stock

In the context of implementing curriculum innovation and teacher learning take the best role to make it happen. The policy to immediately realize the curriculum and learning innovations that emphasize the formation of attitudes, understanding the concept of knowledge, and skills can be realized if there is active participation and awareness of teachers, given the task of teachers in carrying out their duties task not only assuming the task of transforming science alone but educate, teaching, training, guiding and motivating learners so that they will be able to carry out their duties and be able to take the best roles of their time in accordance with the demands of their work world.

The various things that teachers need to realize in implementing curriculum 2013 include: Development of cognitive aspects of curriculum 2013 requires understanding from low level to high level (quality thinking skill). In addition, the necessary interpersonal skills face future demands, not only in terms of what graduates earn, but with regard to how they are earned. Furthermore, the development of the community is strongly influenced by the development and development of human quality, which is expected to be able to be independent, and can adapt to other parties. As expressed by John 
Micklethwait and Adrian Wooldridge, globalization demands are driven by three engines of globalization - international technology, global capital markets, and global management. 4 This situation has brought negative impact to the community, not to mention the students and students. Globalization that has created a more open and transparent world brings with it foreign culture and values. In this context, teachers are expected not only to teach as a 'routine' of carrying out obligations, but to the calling of the soul, by trying to educate the prepared generation to provide exemplary examples to learners. So that they are able to display the noble character in their life as the purpose of education.

The preparatory steps which teachers have done to implement curriculum 2013 are: to learn the essence of curriculum 2013, to make and prepare lesson plans, design media, techniques and assessment rubrics, follow advanced workshops and receive information from resource persons, read the rules related to the implementation of learning and assessment of KI-1, KI-2, KI-3, KI-4, and discussion to improve understanding, and follow KKG and socialize and collect various sources. The various steps that teachers have prepared to implement curriculum 2013 is to prepare mentally, read the rules, attend workshops or trainings on RPP and assessment tools and instruments, and the media is a proactive step for teachers to implement curriculum 2013 professionally.

The policy to immediately implement curriculum 2013 is accompanied by preparations that make it easier for teachers to implement the syllabus, teacher's books and student books so that the teachers are prepared to prepare lesson plans (RPP) based on the government-prepared syllabus. In preparing the RPP teachers are required to develop creativity to foster the ability of students in communicating effectively, systematic and critical thinking, using moral judgment in solving a problem, as well as being a responsible, tolerant, interested and working citizen. As stated by Sanjaya Vienna the task of the teacher is to prepare the human generation to live and play an active role in society. Therefore the work of teachers is not a static job, but dynamic work that must always be in accordance with the development of science and technology and the demands of the dynamics of the development of society. ${ }^{5}$

\footnotetext{
${ }^{4}$ Jhon Micklethwait dan Adrian Wooldridge, 2000, A Future Perfect: the Challenge and Hidden Promise of Globalization. New York: Crown Business, hal. 102

${ }^{5}$ Wina Sanjaya, 2010, Strategi Pembelajaran Berorientasi Standar Proses Pendidikan, Jakarta: Kencana, hal. 16
} 


\section{Siti Halimah}

Inhibiting factors and support to implement the Curriculum 2013. Inhibiting factors are: lack of facilities and infrastructure to develop the learning process, the curriculum of teacher books and student books, the lack of teachers' knowledge about the method of learning, lack of guidance, time constraints to assess all aspects, inadequate and lack of books and teacher books and books, there are teachers who do not have syllabus and teacher book, lack of socialization and difficulty administration. While the supporting factor is the existence of the means to develop the material, the support of the manager and the Ministry of Religious, has received training on the implementation of curriculum 2013, have awareness to make changes, have knowledge and understanding of the essence of curriculum 2013, preparing the RPP based on syllabus that has been prepared.

Teachers play an important role in implementing a curriculum change. Although the teacher does not self-conceptualize the curriculum, but the translator teacher changes a curriculum. The teacher will translate the changes of a curriculum by learning and assessing the curriculum outcomes. Teacher assessment results will greatly help curriculum development to understand the barriers in curriculum implementation. On that basis, the change of a curriculum will be taken seriously by teachers in relation to the field of tasks that will be executed as the curriculum implementer.

An innovation (change) including curriculum change generates a counterresponse (accept and reject) among teachers. Although teachers generally understand that a change or innovation implies a change from an old state to be better. The wave of change in a curriculum is accompanied by different responses. Such phenomena arise in connection with the existence of the recipient of the change. There are several types of people who respond to a change or innovation, namely: ${ }^{6}$ (1) Early adapters, are people who instantly accept change; (2) Early Majority, are people who recognize the need for change but not directly receive it / learn first (hopeful). (3) Undecided, are people waiting where the wind is blowing (fence sutter); (4) Late majority, are people who are anxious about the developing conditions, especially the effect of change on him; (5) Late adapters, are those that openly resist change (resistant). Resistant circles are believed to always be in the process of change. Likewise, teachers receive curriculum changes from those

\footnotetext{
${ }^{6}$ Udin Syaefudin Saud (2012), Inovasi Pendidikan, Bandung: Alfabeta, hal.
} 
enacted beforehand, because teachers are aware that in the context of changing educational curricula is a human effort to humanize humanity.

\section{CONCLUSION}

To get good curriculum result, the implementation of curriculum 2013 needs to be done by implementing integrity between disciplines by using an integrated model. This model requires the teacher's expertise and ability to relate between one field of study and other fields properly and correctly according to the pattern, objectives and demands of the 2013 curriculum.

\section{BIBILIOGRAPHY}

Al Rasyidin, Makalah Seminar Nasional," Membangun Pendidikan Karakter: Sketsa Masalah dan Gagasan tentang Pendidikan Karakter", tanggal 02-2-2011. Rantau Prapat.

Micklethwait, Jhon dan Adrian Wooldridge. A Future Perfect: the Challenge and Hidden Promise of Globalization. New York: Crown Business, 2000.

Regulation of Ministry of Education and Culture Republic of Indonesia Number 20, 2016 about Competence Standard of Graduation of Elementary and Secondary Level Regulation of Ministry of Education and Culture Republic of Indonesia Number 21, 2016 about Content Standard of Graduation of Elementary and Secondary Level Regulation of Ministry of Education and Culture Republic of Indonesia Number 22, 2016 about Process Standard of Graduation of Elementary and Secondary Level Regulation of Ministry of Education and Culture Republic of Indonesia Number 23, 2016 about Evaluation Standard of Graduation of Elementary and Secondary Level

Regulation of Ministry of Education and Culture Republic of Indonesia Number 24, 2016 about Core Competence and Basic Competence Curriculum of 2013 at Elementary and Secondary Level

Sanjaya Wina, (2010), Strategi Pembelajaran Berorientasi Standar Proses Pendidikan, Jakarta:

Kencana

Syaefudin Saud, Udin, (2012), Inovasi Pendidikan, Bandung: Alfabeta

Syukmadinata, Nana Syaodih, (2011), Pengembangan Kurikulum: Teori dan Praktek, Bandung: Remaja Rosdakarya 